\title{
Aspect Acquisition in Russian as the Weaker Language: Evidence from a Turkish-Russian Child
}

\begin{abstract}
:
Aims and Objectives/Purpose/Research Questions:

This study aims to contribute to the discussion about the weaker language development by examining the effect of the restricted input and use on the acquisition of the morphological category of aspect in Russian by a Turkish-Russian bilingual child in a Turkish-dominant environment. The main goal the study pursues is to investigate whether the reduced input and restricted use of Russian, mainly through communication with a Russian-speaking mother, is still sufficient for monolingual-like acquisition of Russian aspect.
\end{abstract}

\section{Design/Methodology/Approach:}

This study is a longitudinal case study.

\section{Data and Analysis:}

The main source of data collection is video and audio recordings. Twenty-five recordings are available. They cover the period of between two years and eleven months $(2 ; 11)$ and $4 ; 0$. First, the data is examined in terms of the availability of perfective and imperfective forms and meanings they express in the Russian language. Then, we look into whether the data of the bilingual child is marked with deviations from the monolingual Russian data in terms of error rates and patterns.

\section{Findings/Conclusions:}

The findings of the study suggest that despite the reduced input, the acquisition of Russian aspect in the Turkish-dominant environment follows the same pattern as a monolingual one does.

\section{Originality, and Significance/Implications:}

The study contributes to the discussion about the weaker language development in bilingual contexts and adds to the growing body of research looking at the development of a particular language in a variety of different contexts.

\section{Keywords}

Bilingual First Language Acquisition, weaker language aspect, Russian-Turkish, reduced input 


\section{Introduction}

"True ambilingual speakers are very rare creatures" (Hoffmann 1991, p. 21) and the majority of bilinguals seldom have equal proficiency in their languages. Moreover, in cases when one of the bilingual's languages is acquired in the absence of the broader community through communication with a family or a parent, the input in the language and opportunities to use it are very restricted, one of the languages of the bilingual runs even a higher risk of becoming weaker and incomplete (Montrul, 2008). Most of the studies investigating such asymmetrical development in bilingual first language acquisition focus on the interaction between the stronger and the weaker language (WL) in the bilingual's repertoire, particularly, on the cross-linguistic influence and codeswitching between them (Dopke, 2000b; Hulk \& Mueller; 2000; Mueller; 1998; Yip \& Matthews, 2007 to name a few). There have been rather fewer studies that explore acquisition of the WL by bilingual children (Bonnesen, 2006; Dopke, 2000a; La Morgia, 2011; Shlyter, 1993; Schlyter \& Hakansson, 1994). These studies focus on the analysis of norm-deviant forms found in the production of their bilingual participants when they speak their WL, and show that acquisition of the WL is marked with more numerous and persistent use of deviant forms than that of their monolingual and balanced bilingual counterparts. However, the interpretation of these deviant forms in the WL differs among the scholars: while Schlyter and Hakansson $(1993 ; 1994)$ suggest that due to the reduced input, acquisition of the WL differs not only quantitatively but also qualitatively and may result in acquisition failure; Dopke (2000a), Bonnesen (2006) and Meisel (2007) argue that acquisition of the WL, by and large, follows monolingual patterns and that the reduced to a certain degree input is unlikely to cause qualitatively different and incomplete acquisition. Though the scholars involved in the debate about the status of the WL have not reached a consensus about whether the reduced input might cause qualitative different and/or incomplete acquisition of the WL, they all acknowledge that if there is such a possibility, "the only feasible explanation could be that the input does not suffice to acquire certain domains" (Bonnesen, 2006, p. 178).

In this line, the present study aims to contribute to the discussion about the WL development by examining the effect of the reduced input and use on the acquisition of the morphological category of Russian aspect (RA) by a Turkish-Russian bilingual child in a Turkish-dominant environment. The main goal the study pursues is to investigate whether the reduced input and restricted use of Russian, mainly through 
communication with a Russian-speaking mother, is still sufficient for monolingual-like acquisition of RA in a Turkish-dominant environment.

Monolingual Russian children are known to be nearly error-free in the use of RA from an early age (Bar-Shalom, 2002; Ceytlin, 2009; Gagarina, 2000, 2007; KiebzakMandera, 1997, 2000; Stoll, 2001), while Russian bilinguals' acquisition of aspect has been reported to be qualitatively different and incomplete, at least, in some bilingual contexts: Hebrew-Russian (Gagarina, Armon-Lotem \& Gupol, 2005), AzerbaijaniRussian (Ceytlin, 2009) and American-Russian (Polinski, 2006, 2007). To our knowledge, the acquisition of RA in a Turkish-dominant environment has not been investigated so far. For these reasons, the acquisition of RA in a Turkish dominant environment has been chosen as the focus of our study, which, by providing unique data and results, is supposed to contribute to the debate about the WL development in bilingual research. Within this framework, this study specifically investigates:

1. Whether the bilingual Turkish-Russian participant can accurately use perfective and imperfective forms in their meanings in Russian as the WL.

2. Whether the data of the bilingual participant is marked with deviations from the monolingual Russian data in terms of error rates and patterns.

Following the above-presented debate about the WL acquisition and the results of the studies examining acquisition of RA in various bilingual contexts, it may be hypothesized that due to the reduced input and restricted use of Russian in the Turkishdominant environment, the acquisition of RA by the bilingual participant will differ qualitatively from the monolingual pattern.

Whilst it might be necessary here to use terms such as "failure" and "incomplete acquisition" to describe non-production of expected or required forms, we by no means imply any sort of incapability of the child to acquire them.

\section{Influence of bilingualism on language acquisition}

The participant of this study has been acquiring Russian in the environment of his dominant Turkish language and with the reduced input. As it was pointed out above, the main goal of this study is to explore the effect of the reduced input on the acquisition of RA. Yet, the bilingual context itself implies a strong possibility of emergence of cross-linguistic influence (CLI). There have been a number of studies demonstrating 
that the production of bilingual children can differ from that of monolinguals and that these differences can be explained due to the influence of one of the bilinguals' languages on the other (to name but a few, Dopke, 2000b; Hulk \& Mueller, 2000; La Morgia, 2011). CLI has been often reported from the dominant to the WL, though bidirectional influence is also possible (Paradis \& Genesee, 1996; Yip \& Matthews, 2007). Among the factors effecting CLI, the concept of typological closeness of languages in contact is considered as the most significant one (Cenoz, 2001; Odlin, 1989 among numerous others). CLI is expected to occur when two languages involved are typologically close, while when they are typologically remote, CLI is unlikely to take place. Additionally, it is also known that not all language domains are vulnerable to CLI. For example, the interface of syntax-semantics and syntax-discourse properties in a language have been reported as vulnerable one (Hulk \& Mueller, 2000; La Morgia, 2011; Montrul, 2004), while inflectional morphology, being too-language specific, is considered as non-susceptible to CLI (Nicoladis \& Paradis, 2012). Relying on these assumptions and the fact that Russian and Turkish are typologically remote languages (for typological characteristics of the languages see below), one will not expect CLI to take place in acquisition of RA by the Turkish-Russian participant.

\section{Typological characteristics of Turkish and Turkish aspect}

Turkish is a member of the Oghuz branch of the Turkic languages belonging to the Uralic and Altaic language family (Comrie, 1987). Turkish is an agglutinating language, in which grammatical functions are realized by suffixation (Kornfilt, 1997). While nouns and pronouns are inflected for number, case and possession, verbs are richly inflected for negation, tense-aspect-mood, number and person. The richness of Turkish agglutinative morphology has been defined as the major factor accounting for the highest speed of language acquisition by monolingual Turkish children if compared with Russian, Croatian, Greek, Finnish, Yucatec Maya, French, Dutch and German monolinguals (Laaha \& Gillis, 2007). The scholars attribute the positive correlation between the richness of morphology and speed of acquisition to the increasing sensitivity of learners to the extensive number of morphological markers in their input. As for the syntax in Turkish, while SOV is canonical (Kornfilt, 1997), for various communicative reasons, inverted orders are also possible (Erguvanl1, 1984).

Regarding the category of aspect in Turkish, it is available only in inflected verb forms and is marked with several suffixes: the perfect aspect is expressed by the verbal 
suffixes, $-(y) D I$ and $-m I s$, and imperfective aspect is expressed by the suffixes $-(I) y o r$, $-m A k t A$ and $-(A / I) r$, and by the past copular marker $-(y) D I$. However, these suffixes do not have aspectual function(s) exclusively since they also express tense and/or mood, nor is a given suffix linked to a given aspect in all syntactic and morphological contexts (Kornfilt, 1997; Goksel \& Kerslake, 2005).

\section{Typological characteristics of Russian and Russian aspect}

Russian is a strongly inflecting language belonging to West-Slavic languages and possessing a very complex noun and verb morphology, which comprises quite a lot of categories such as case, number and gender for nouns and aspect, tense, mood for verbs, all of which are richly developed. Russian morphology is fusional and is marked with numerous morphophonemic alterations. There is an extensive agreement system between different parts of speech in the sentence. Russian, is known for so called freeword order, and the place of major constituents in the sentence is determined not by their syntactical functioning but by pragmatic factors such as topic and focus. Since the focus of this study is on RA acquisition, a detailed description of the RA system is necessary.

\subsection{The Russian aspect system}

The RA system consists of a binary opposition of a perfective and an imperfective aspect, and each Russian verb form, including infinitives, can be categorized as one of these two aspect categories.

\subsubsection{Formation}

Morphologically, there is no unique feature indicating that a verbal form is perfective or imperfective, which makes the analysis and acquisition of RA rather complex. Nevertheless, the core pattern of RA formation, tripartite, has been proven to be the most productive one when describing and analysing the RA system (Brecht, 1984; Kartsevskii, 1927; Timberlake, 2004). Accordingly, Russian verb forms lacking any prefixes, e.g. nucamb [pisat']-IMPER (write) are known as simplexes and they report continuous situations. These simplexes are imperfective, as a rule. The simplexes can combine one or more of eighteen prefixes of Russian, which along with adding to/altering the semantics of the simplexes, change the imperfective aspect into 
perfective, e.g. nepe-nucamb [pere-pisat']-PER (copy). Many of these prefixes have qualitative senses, which "present an activity as a series of continuous changes leading towards a limit" (Timberlake, 2004, p. 406). These prefixed perfectives with qualitative meaning allow secondary imperfectives to be formed through the addition of derivational suffixes $-u в /-b l в,-a /-a \check{u},-в a /-в a и ̆$ or $-u в a-/ b l в a-[-i v /-y v,-a /-a j,-v a /-v a j$ or-iva-/yva]-, e.g. nере-nис-blвa-mь [pere-pis-yva-t']-IMPER (copy), and both of them: prefixed perfective and secondary imperfective, form an unambiguous aspectual pair. Because simplexes generally are imperfective, one or another of the prefixed perfectives makes the perfective counterpart to the simplex imperfective.

It is also necessary to say that some of imperfectives can form perfectives via suffixation, e.g. пинать [pinat']-IMPER - пнуть [pnut']-PER (kick) or suppletively e.g. говорить [govorit']-IMPER - сказать [skazat']-PER (say) (Maslov, 1984; Kamynina, 1999).

Furthermore, the RA system is marked with numerous exceptions, which make the task of learners even more complex. Table 1 below summarizes a set of rules and exceptions "a native speaker could form about RA formation while acquiring it" (Stoll, 2001):

Table 1: Aspect formation rules in Russian

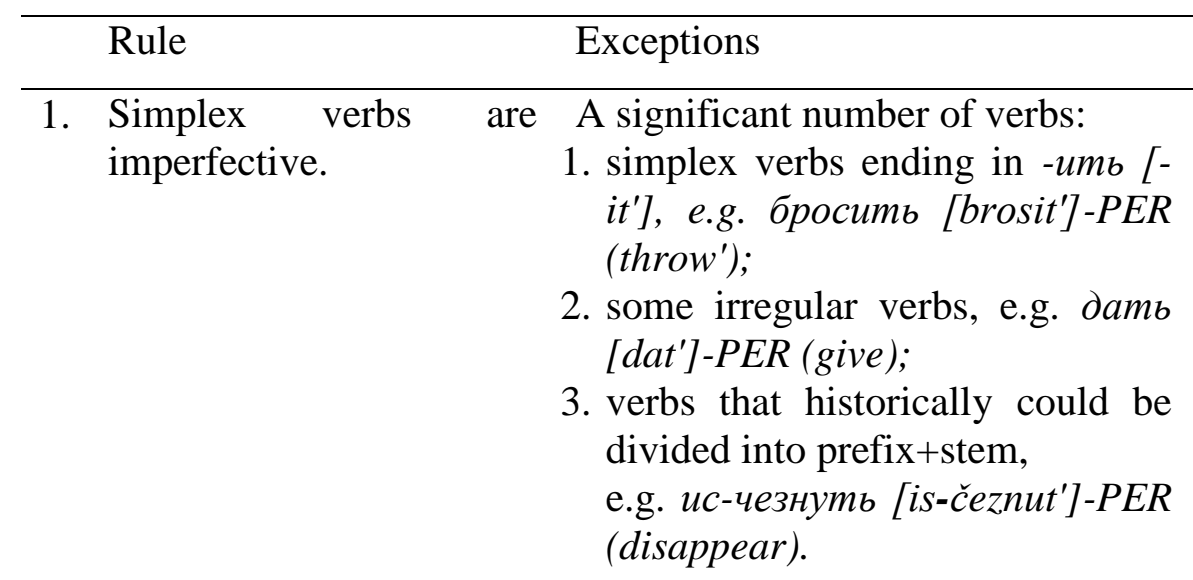

2. If a verb has one of the Double prefixation, such as [no-bblsuffixes -uв/-blв, -a/-aŭ, - таск-uв-amb] [po-vy-task-iv-at']ва/-вай or -ива-/blва- [- PER (pull out), which are $i v /-y v,-a /-a j,-v a /-v a j$ or - perfective. Notes $i v a-/-y v a]$ then the verb must be imperfective.

Rule 1 and 2 are ordered in a hierarchy, so that in case of conflict, Rule 1 overrides Rule 2. 
3. If a verb has a prefix, then Some borrowings from Old Church the verb is perfective. Slavic and other languages as well as prefixed motion verbs, e.g. $3 a-$ висеть [za-viset']-IMPER (depend).

4. Verbs with the suffix $-\mu y$ - A significant number of verbs, e.g. [-nu-] are perfective. гнymb [gnut']-IMPER (bend).

In addition to these rules of aspect formation and exceptions, there is a group of Russian verbs that form the classes of perfective tantum (they have no imperfective counterpart), imperfective tantum (they have no perfective counterpart) and bi-aspectual verbs (aspect determination of them in a neutral context is not possible).

\subsubsection{Meanings}

The acquisition of RA is not restricted to decoding and encoding aspectual forms, but also requires learners to know the variety of functions perfective and imperfective forms can express, as well as to define the cases where both forms can be used interchangeably, which also complicates acquisition of RA. Though most of definitions of aspect rely on the notion of totality and time localization of the perfective aspect in contrast to duration and non-totality of the imperfective aspect (Bybee, 1992; Comrie, 1987; Timberlake, 1993), they neither cover the whole spectrum of meanings perfective and imperfective forms can express nor define cases when both imperfective and perfective aspects can be used synonymously. Therefore, in order to understand the use of RA, it is essential to consider all possible functional contents imperfective and perfective forms can express and focus on the specific meanings of both aspects (Maslov, 1984). Table 2 developed by Bondarko (1971, p. 16) presents possible semantic contexts of the perfective and imperfective aspects.

Table 2: Semantic contents of RA

\begin{tabular}{llllllll}
\hline $\begin{array}{l}\text { Semantic } \\
\text { content }\end{array}$ & Totality & Process & $\begin{array}{l}\text { Time } \\
\text { localization }\end{array}$ & Duration & $\begin{array}{l}\text { Sudden } \\
\text { onset }\end{array}$ & Consequence & Synchronism \\
Perfective & + & - & $(-)+$ & $-(+)$ & $(-)+$ & $(-)+$ & $(-)+$ \\
İmperfective & $-(+)$ & -+ & -+ & -+ & $-(+)$ & $-(+)$ & $(-)+$ \\
\hline
\end{tabular}

Within the variety of the context possibilities defined in Table 2, there are several specific meanings perfective and imperfective aspects can express (Bondarko, 1971; Maslov, 1984; Kamynina, 1999). Table 3 below presents five meanings Russian 
imperfective aspect expresses (most examples are presented in the way they appear in Kamynina, 1999):

Table 3: Meanings of Russian imperfective aspect

\begin{tabular}{ll}
\hline Meaning & Eхатрle \\
\hline 1. Concrete-processive & За окном светит-IMPER солнце и сльишны \\
imperfective describing a lasting & голоса детей. \\
action taking place in a concrete & Za oknom svetit-IMPER solnce $i$ slyšny \\
situation & golosa detej. \\
& [behind window shine-IMPER sun and heard \\
& voices children's] \\
& 'The sun is shining and children's voices are \\
& heard outside.'
\end{tabular}

2. Imperfective for repeated Иногда встречаешь-IMPER старого друга situations и наговориться с ним не можешь.

Inogda vstrečaeš'-IMPER starogo druga $i$ nagovorit'sja s nim ne možeš'.

[sometimes you meet-IMPER old friend and (to) talk your fill with him (you) not can] 'Sometimes you meet your old friend and cannot stop talking with him.'

3. Common-factual imperfective Это был прекрасный слесарь - он легко describing an action happening открывал-IMPER самые сложные замки. during a certain unidentified Èto byl prekrasnyj slesar'-on legko otkryvalperiod IMPER samye složnye zamki.

[that was wonderful locksmith he easily opened-IMPER the most difficult locks] 'He was a wonderful locksmith - he opened the most difficult locks easily.' 
4. Imperfective describing Люблю-IMPER я утренний запах constant attitude to a situation свежести.

Ljublju-IMPER ja utrennij zapah svežesti.

[love-IMPER I morning smell (of) freshness]

'I love a fresh smell of an early morning.'

5. Imperfective for Живешь на соседней улице, а видишьсяconstant/typical characteristics IMPER раз в год.

of an object or a situation Živeš' na sosednej ulice, a vidiš'sja-IMPER raz $v$ god.

[you live on neighbour street, and see (each other)-IMPER once in year ]

'You live in the next street but we see each other not more than once a year.'

The perfective aspect expresses the following five meanings in Russian, which are presented in Table 4.

Table 4: Meanings of Russian perfective aspect

Meaning Example

1. Concrete-factual describing a Это был прекрасный слесарь - он легко concrete single action or event открыл-PЕR тот сложный замок.

Èto byl prekrasnyj slesar' - on legko otkrylPER tot složnyj zamok.

[that was wonderful locksmith he easily opened-PER that difficult lock]

'That was a wonderful locksmith - he opened that difficult lock easily'.

2. Perfective for actions that follow Саша вошел-PER в комнату, сел-PER за one after another in a concrete стол $u$ увидел-PER стопку situation непрочитанных писем. 
Saša vošel-PER v komnatu, sel-PER za stol $i$

uvidel-PER stopku nepročitannyh pisem.

[Sasha entered-PER in room, sat-PER at desk and saw-PER heap (of) unread letters]

'Sasha entered the room, sat at the desk and saw the heap of unread letters.'

3. Perfective summarizing two or Диана дважды напомнила-PER ему о more equal concrete situations своей просьбе.

Diana dvaždy napomnila-PER eтu o svoej pros'be.

[Diana twice reminded-PER him about her request]

'Diana reminded him of her request twice.'

4. Perfective describing a typical Иногда встретишь-PER старого друга $и$ example in repeated situations наговориться с ним не можешь.

Inogda vstretiš'-PER starogo druga $i$ nagovorit'sja s nim ne možeš'.

[sometimes (you) meet-PER old friend and (to) talk your fill with him you not can] 'Sometimes you meet your old friend and cannot stop talking with him.'

5 Perfective identifying Живешь на соседней улище, а увидишьсяpossibilities in repeated PER раз в год.

situations Živeš’ na sosednej ulice, a uvidiš’sja-PER raz $v$ god.

[you live on neighbour street, and you see (each other)-PER once in year]

'You live in the next street but we see each other not more than once a year.' 
As mentioned above, in some cases perfective and imperfective forms can be used interchangeably without significant changes in the meaning of the utterance. Bondarko (1971) and Maslov (1984) define three perfective-imperfective meanings that can be used synonymously:

1. Perfective forms with concrete-factual meaning and imperfective forms with common-factual meaning;

2. Perfective forms describing a typical example in repeated situations and imperfective forms describing repeated situations that occur limited or unlimited number of times;

3. Perfective forms used identifying possibilities in repeated situations and imperfective forms describing constant or typical characteristics of an object or a situation.

To summarize, RA is a complex system incorporating an intricate set of aspect formation rules and exceptions to them, as well as comprising a variety of meanings perfective and imperfective forms can fulfil in Russian.

\section{Acquisition of Russian aspect by monolingual children}

Scholars examining acquisition of RA (Bar-Shalom, 2002; Ceytlin, 2000; Gagarina, 2000, 2007; Gvozdyev, 1961, 1981; Pupynin, 1996; Stoll, 2001; Vinnitskaya \& Wexler; 2001) report early and accurate use of aspect in all its meanings by monolingual children. Both forms, perfective and imperfective, appear among first verbs in the children's speech. Initially, children acquire the concrete-factual meaning of perfective forms and the concrete-processive meaning of imperfective verbs. Though there are some situations when both aspects, perfective and imperfective, can be used synonymously in Russian (Bondarko, 1971; Maslov, 1984), monolingual children mostly rely on the criteria of completeness-incompleteness and totality-non-totality of the action when choosing an aspectual form, which in turn may result in rare overuses of aspects (see Example 1) (Ceytlin, 2000; Gvozdyev, 1961). The major error pattern related to the use of aspect found in monolingual Russian acquisition is errors in the formation of perfective and imperfective forms, that is children identify the required aspectual form correctly but use incorrect suffix/prefix(es) to form it (see Example 3). Some scholars (Ceytlin, 2000) define such errors as child innovations. Even at the age 
of about six $(6 ; 0)$, the acquisition of aspect is not completed, and errors in the formation as well as rare overuses of both, perfective and imperfective forms, are recorded by recent studies.

\section{Acquisition of Russian aspect in a bilingual context}

There have been a few studies that examine the acquisition of RA in bilingual contexts, and they report quite a different pattern of RA acquisition by a bilingual population if compared with monolinguals. Gagarina, Armon-Lotem and Gupol (2005) investigate the development of early Russian verbal morphology in successive Russian-Hebrewspeaking bilinguals and compare their findings with monolingual acquisition. The monolingual data come from three Russian children at the age from 2;0 to $2 ; 10$; the bilingual data are obtained from eight Russian-Hebrew bilingual children aged from 3;06 to 5;0. All but one are successive bilinguals with Russian as the L1 and dominant. The main focus of the study is on the analysis of errors made by the monolingual and bilingual children. Gagarina et al. (2005) reveal that the bilinguals' errors exhibit a clearly different pattern; namely, incorrect use of aspect (imperfective in place of perfective and vice versa) is a prominent part of all the errors. Gagarina et al. (2005) state that the number of aspectual errors increases significantly over the time in the bilingual group. The scholars conclude that while errors found in the monolingual acquisition are typical for the developmental phase of the children, errors found in the language of the successive bilinguals are atypical for monolinguals with similar syntactic abilities, and can be attributed either to delay in achieving full mastery of the morphological system, to attrition or to the L2 influence of Hebrew, which does not mark aspect morphologically. Error analysis is also applied in the study of Ceytlin (2009), who aims to reveal significant differences in the development of verbal morphology in Russian between monolingual and bilingual young learners. The monolingual group consists of Russian speaking monolingual children at the age from $2 ; 0$ to $3 ; 0$. The bilingual group is formed of successive bilinguals at the age from $6 ; 0$ to 9;0 with Azerbaijani as their L1. Relying on the analysis of the participants' performance related to the use of perfective and imperfective forms, Ceytlin (2009) finds out a significant difference in the error rates and patterns between the Russian monolingual and Azerbaijani-Russian bilingual groups. The monolingual children demonstrate an accurate differentiation between the perfective and imperfective aspect; however, they may make a few errors when forming perfective or imperfective forms. 
In the data from the Azerbaijani-Russian bilingual participants, on the other hand, errors are of a different pattern. The overuses of imperfective forms in place of perfective and vice versa prevail considerably in the bilingual children's production. Ceytlin (2009) relates these errors to incomplete understanding of semantics of Russian verbs. In another study, Polinski (2006, 2007) demonstrates that aspect in American Russian is expressed in a very different way than in standard Russian. To be precise, it appears as a lexical category, which is reflected in the fact that verbs do not form aspectual pairs, that is one form, either imperfective or perfective, is retained, while the other is lost. Verbs of achievement and accomplishment are clearly favoured in the perfective form, while verbs denoting process and states are preferred in the imperfective form. Polinski $(2006,2007)$ underlines that only speakers with the highest level of proficiency manage to retain both aspectual forms.

To sum up, the review of the studies on acquisition of RA in monolingual and bilingual contexts reveals that while monolingual children can accurately distinguish between perfective and imperfective aspect from very early ages and their errors mostly occur due to the incorrect formation of aspectual forms, bilingual children make numerous errors while using RA, the pattern of which differs from that of monolinguals and is related to overuse of perfective in place of imperfective or vice versa.

\section{Method}

\subsection{Participant}

The participant of the present study is S., the son of the first author. S. is born in Ankara, Turkey, and he is the only child of the family. From birth, S. has been exposed to two languages, Turkish and Russian. However, Turkish has been dominant in the child's linguistic environment. S.'s father, who is a native speaker of Turkish and does not speak Russian, always addresses S. only in Turkish. Turkish is also used for communication among the members of the family. Besides, S. constantly hears Turkish from Turkish friends, relatives and people outside during visits to public places. At the age of $2 ; 0, \mathrm{~S}$. starts attending playgroups, where he plays with Turkish children for about three hours three times a week. S.'s Russian input comes from his mother, who never sticks to the one-parent-one-language approach and addresses S. in both Russian and Turkish often switching between them. However, from the age of two months $\mathrm{S}$. 
has been read Russian books regularly (about two-three hours a week). S. has never been to Russia but his Russian relatives visit Turkey two to three times a year for twothree weeks from the time when S. is 10 months old. As a result of such an imbalance between the languages, at the age of 1;07, when S.'s first words appear, predominantly all of them are in Turkish with few exceptions in the form of indeterminate utterances, which with the further language development are clarified to be Turkish as well. At the age of 2;0, S. starts to produce two-word utterances in Turkish, and four months later, he turns into a talkative Turkish-speaking child. Yet, in the everyday family interaction, it is clear that S. is also able to understand Russian, but he persistently refuses to produce a single word in Russian. In order to trigger S.'s Russian production, monolingual Russian relatives are invited to come to Turkey for about six weeks when $\mathrm{S}$. is at the age of 2;04. It is a real push for S.'s Russian language development though he still prefers to speak Turkish whenever possible, and his Russian, being marked with numerous instances of mixing from Turkish, is difficult to understand for Russian monolinguals sometimes.

\subsection{Data collection and transcription}

The main source of data collection is video and audio recordings. Twenty-five recordings are available. They cover the period of between $2 ; 11$ to 4;0. The recordings are made once every two weeks for at least 30 minutes each time (following De Houwer, 1990). The recordings are made in the Russian context when the child is addressed in Russian. The child is recorded in different situations, such as at home, in a friend's house, at a hotel, at the seaside, in shops, at the airport, and with different interlocutors: Russian monolinguals only, Russian monolinguals and Russian-Turkish bilinguals together, Russian-Turkish bilinguals, Russian-Turkish bilinguals and Turkish monolinguals together, and Russian monolinguals and Turkish monolinguals together. Although S. is aware that a recording is being made, he is not aware that his Russian is of particular interest and he does not mind being recorded. All the recordings are transcribed as soon as possible after the event using the CHAT format of CHILDES and later double-checked by two other native speakers of Russian.

\subsection{Data analysis}

In order to investigate the use of aspect forms in Russian by S., first all aspectual forms, found in all the verbal forms emerging in the child's speech: infinitives, indicative, 
subjunctive and imperative verbs, are identified as correct and incorrect by two native speakers of Russian, who have degrees in Russian philology. Further, the number of correct and incorrect uses of aspect forms (perfective and imperfective) is calculated. The incorrect use of an aspect is identified if at least one of the following conditions is fulfilled:

1. The overuse of aspect, that is perfective is overused in place of imperfective or vice versa, as illustrated in Example 1. Example 2 below provides the correct version of this sentence.

(1)

$\begin{array}{ll}\text { He *убери } & \text { машины. } \\ \mathrm{Ne} \text { *uberi } & \text { mašiny. } \\ \text { [not *take-PER-IMP } & \text { car-ACC-PL] } \\ \text { 'Do not take the cars away.' }\end{array}$

(2)
Не убирай
машины.
Ne ubiraj
mašiny.
[not *take-IMPER-IMP
car-ACC-PL]
'Do not take the cars away.'

2. The incorrect formation of perfective and/or imperfective forms such as incorrect suffix/prefix omission, alteration or addition, as illustrated in Example 3. Example 4 below provides the correct version.

(3)
$\mathrm{OH}$
волосики
*по-рас-чесал.
On
volosiki
*po-ras-česal.
[he-NOM hair-ACC-PL
comb-PER-P-SG-M-incorrect double prefixation]

'He combed his hair.'

(4)

Он волосики рас-чесал. 
$\begin{array}{lll}\text { On } & \text { volosiki } & \text { ras-česal. } \\ \text { [he-NOM } & \text { hair-ACC-PL } & \text { comb-PER-P-SG-M] }\end{array}$

'He combed his hair.'

Second, the analysis of the meanings expressed by perfective and imperfective forms found in S.'s production is based on the verbs in the indicative mood only (Kamynina, 1999).

\section{Results}

\subsection{Imperfective aspect in S.'s production}

The data analysis shows that there are 1047 instances of imperfective forms found in S.'s data and 1044 of them are correct, which is equal to more than $99 \%$ of the correct use of the imperfective aspect. Table 5 presents the distribution of imperfective verb forms used by S. during the data collection period. Table 5 presents the use of imperfective forms in S.'s data.

Table 5: Use of the imperfective aspect in S. 's production

\begin{tabular}{llllllll}
\hline Age & Total & Correct & $\%$ & Age & Total & Correct & $\%$ \\
\hline $2 ; 11.09$ & 29 & 29 & 100 & $3 ; 06.02$ & 12 & 12 & 100 \\
$2 ; 11.23$ & 8 & 8 & 100 & $3 ; 06.26$ & 33 & 33 & 100 \\
$3 ; 0.12$ & 13 & 13 & 100 & $3 ; 07.08$ & 31 & 31 & 100 \\
$3 ; 01.10$ & 13 & 13 & 100 & $3 ; 07.21$ & 101 & 101 & 100 \\
$3 ; 01.25$ & 45 & 45 & 100 & $3 ; 08.06$ & 71 & 71 & 100 \\
$3 ; 02.08$ & 18 & 18 & 100 & $3 ; 08.21$ & 64 & 64 & 100 \\
$3 ; 02.25$ & 18 & 18 & 100 & $3 ; 09.07$ & 47 & 47 & 100 \\
$3 ; 03.06$ & 45 & 42 & 93 & $3 ; 09.16$ & 67 & 67 & 100 \\
$3 ; 03.13$ & 37 & 37 & 100 & $3 ; 10.0$ & 73 & 73 & 100 \\
$3 ; 04.09$ & 38 & 38 & 100 & $3 ; 10.25$ & 68 & 68 & 100 \\
$3 ; 04.19$ & 32 & 32 & 100 & $3 ; 11.09$ & 56 & 56 & 100 \\
$3 ; 05.06$ & 27 & 27 & 100 & $4 ; 0.02$ & 74 & 74 & 100 \\
$3 ; 05.19$ & 27 & 27 & 100 & & & & \\
\hline
\end{tabular}

As it is evident from Table 5, imperfective forms appear in the child's production from the first recording session, that is at the age of 2;11.09. Example 5 presents one of the correct imperfective forms used by S.: 
(5)
S. $(2 ; 11.09): \quad T b l$
разрешаешь?
S. $(2 ; 11.09): \quad$ Ty
razrešaěs?'
[you-NOM-SG
allow-IMPER-PR-2PRS-SG]

S. (2;11.09): 'Do you allow?'

The very high percentage of the correct use of imperfective forms in the child's data enables us to conclude that S. can use the imperfective aspect productively and he does not encounter difficulties while using it.

\subsection{Meanings of imperfective forms found in S.'s data}

The analysis of S.'s data reveals that all the five meanings of the imperfective aspect are found in his production. The data analysis shows that there are 236 correct cases when S. uses an imperfective form for describing a lasting action taking place in a concrete situation, as Example 6 illustrates:

(6)
S. (3;04.09): $\quad$ А здесь лягушка
npblzaem.
S. (3;04.09): Azdes' ljaguška prygaet.
[and here frog-NOM-SG jump-IMPER-PR-3PRS-SG]

S. (3;04.09): $\quad$ 'And here there is a frog jumping.'

Correct imperfective forms for repeated situations appear in the child's production 16 times. Example 7 is typical:

(7)

$\begin{array}{llllll}\text { S. (3;10.0): } & \text { Иногда } & \text { от } & \text { ветра } & \text { болит } & \text { животик. } \\ \text { S. (3;10.0): } & \text { Ínogda } & \text { ot } & \text { vetra } & \text { bolit } & \text { životik. } \\ & \text { [sometimes } & \text { from } & \text { wind-GEN- } & \text { ache-IMPER- } & \text { stomach- } \\ & & & \text { SG } & \text { PR-3PRS-SG } & \text { NOM-SG] }\end{array}$

S. (3;10.0): 'Sometimes the stomach aches because of the wind.'

The data analysis reveals that the majority of the correct imperfective forms found in the corpus belong to common-factual imperfectives, which describe an action taking 
place during a certain unidentified period of time. S. uses common-factual imperfective forms 684 times in his speech. Example 8 is typical:

$\begin{array}{lllll}\text { S. (3;04.19): } & \text { Да, } & \text { она } & \text { знает } & \text { дорогу. } \\ \text { S. (3;04.19): } & \text { Da, } & \text { опа } & \text { znaet } & \text { dorogu. } \\ & \text { [yes } & \text { she-NOM } & \text { know-IMPER-PR-3PRS- } & \text { road-ACC-SG] } \\ & & & \text { SG }\end{array}$

S. (3;04.19): 'Yes, she knows the road.'

There are 22 correct examples in the corpus when S. uses imperfective forms for describing constant attitude to a situation. Example 9 illustrates one of them: (9)
S. $(3 ; 01.10): \quad$ Я
люблю
конфетки.
S. $(3 ; 01.10)$ :
$\mathrm{Ja}$
ljublju
konfetki.
[I-NOM love-IMPER-PR-1PRS-SG
candy-ACC-PL]
S. (3;01.10): 'I love candies.'

The last function of an imperfective form, that is describing constant or typical characteristics of an object or a situation, is found in the child's production 86 times used correctly. Example 10 is typical:
S. (3;07.21): $\quad$ У него
ручки
крутятся.
S. $(3 ; 07.21)$ :
U nego ručki
[at he-GEN hand-NOM-PL
krutjatsja.
turn-IMPER-PR-3PRS-PL]

S. (3;07.21): 'His hands can turn.'

Relying on the examples and data analysis presented above, we can conclude that $\mathrm{S}$. has acquired all meanings of the imperfective aspect in Russian.

\subsection{Perfective aspect in S.'s production}

The data analysis shows that there are 838 instances of perfective forms found in S.'s data and 832 of them are correct, which is equal to more than $99 \%$ of the correct use of the perfective aspect. Table 6 presents the distribution of perfective verb forms used by S. during the data collection period. 
Table 6: Use of the perfective aspect in S. 's production

\begin{tabular}{llllllll}
\hline Age & Total & Correct & $\%$ & Age & Total & Correct & $\%$ \\
\hline $2 ; 11.09$ & 20 & 20 & 100 & $3 ; 06.02$ & 16 & 16 & 100 \\
$2 ; 11.23$ & 15 & 15 & 100 & $3 ; 06.26$ & 37 & 37 & 100 \\
$3 ; 0.12$ & 19 & 19 & 100 & $3 ; 07.08$ & 21 & 20 & 95 \\
$3 ; 01.10$ & 7 & 7 & 100 & $3 ; 0721$ & 57 & 56 & 98 \\
$3 ; 01.25$ & 40 & 40 & 100 & $3 ; 08.06$ & 64 & 63 & 98 \\
$3 ; 02.08$ & 20 & 20 & 100 & $3 ; 08.21$ & 51 & 51 & 100 \\
$3 ; 02.25$ & 26 & 26 & 100 & $3 ; 09.07$ & 73 & 73 & 100 \\
$3 ; 03.06$ & 14 & 14 & 100 & $3 ; 09.16$ & 49 & 49 & 100 \\
$3 ; 03.13$ & 26 & 26 & 100 & $3 ; 10.0$ & 35 & 35 & 100 \\
$3 ; 04.09$ & 12 & 11 & 92 & $3 ; 10.25$ & 57 & 57 & 100 \\
$3 ; 04.19$ & 35 & 33 & 94 & $3 ; 11.09$ & 48 & 48 & 100 \\
$3 ; 05.06$ & 21 & 21 & 100 & $4 ; 0.02$ & 47 & 47 & 100 \\
$3 ; 05.19$ & 28 & 28 & 100 & & & & \\
\hline
\end{tabular}

As it is evident from Table 6, perfective forms appear in the child's production from the first recording session. Example 11 presents one of the correct perfective forms used by S.:

$\begin{array}{lllll}\text { S. }(2 ; 11.09): & \text { Они } & \text { упали, } & \text { не } & \text { сломались. } \\ \text { S. }(2 ; 11.09): & \text { Oni } & \text { upali, } & \text { ne } & \text { slomalis'. } \\ & \text { [they-NOM } & \text { fall-PER-P-PL } & \text { not } & \text { break-PER-P-PL] }\end{array}$

S. (2;11.09): 'They fell down, they did not break.'

The very high percentage of the correct use of perfective forms in the child's data enables us to conclude that $\mathrm{S}$. can use the perfective aspect productively and he does not encounter difficulties while using it.

\subsection{Meanings of perfective forms found in S.'s data}

The analysis of S.'s data reveals that all the five meanings of the perfective aspect are found in his production.

The majority of perfective forms found in the data belong to the concrete-factual meaning of the perfective aspect, which identifies a concrete single action or event. There are 623 correct instances of concrete-factual perfective forms in S.'s corpus and Example 12 demonstrates one of them: 


$$
\begin{array}{llll}
\text { S. }(2 ; 11.23): & Я & \text { сам } & \text { сделал. } \\
\text { S. }(2 ; 11.23): & \text { Ja } & \text { sam } & \text { sdelal. } \\
& \text { [I-NOM } & \text { myself } & \text { do-PER-P-SG-M] }
\end{array}
$$

S. $(2 ; 11.23): \quad$ 'I did it myself.

Correct perfective forms describing actions that follow one after another in a concrete situation appear in the child's production 180 times. Example 13 is illustrative:

$\begin{array}{lllll}\text { Мама: } & \text { Кто } & \text { тебе } & \text { купил } & \text { автобус? } \\ \text { Мата: } & \text { Kto } & \text { tebe } & \text { kupil } & \text { avtobus? } \\ & \text { [who-NOM } & \text { you-DAT-SG } & \text { buy-PER-P-SG-M } & \text { bus-ACC-SG] }\end{array}$

Mother: 'Who bought you the bus?'

$\begin{array}{llllllll}\text { S. (3;01.10): } & \text { Никто; } & \text { я } & \text { когда } & \text { рылку } & \text { покушал, } & \text { тыл } & \text { дал. } \\ \text { S. (3;01.10): } & \text { Nikto; } & \text { ja } & \text { kogda } & \text { rybku } & \text { pokušal, } & \text { ty } & \text { dal. } \\ & \text { [nobody } & \text { I- } & \text { when } & \text { fish-ACC- } & \text { eat-PER- } & \text { you- } & \text { give-PER- } \\ & & \text { NOM } & & \text { SG } & \text { P-SG-M } & \text { NOM } & \text { P-SG-M] }\end{array}$

S. (3;01.10); 'Nobody did, when I ate my fish, you gave them to me.'

The data analysis reveals that there are two instances of perfective forms summarizing two or more equal situations. Example 14 presents one of them:

$$
\begin{array}{llllll}
\text { S. }(3 ; 10.25): & \text { Я } & \text { на } & \text { турецком } & \text { много } & \text { посмотрел. } \\
\text { S. }(3 ; 10.25): & \text { Ja } & \text { na } & \text { tureckom } & \text { mnogo } & \text { posmotrel. } \\
& \text { [I-NOM } & \text { on } & \text { Turkish } & \text { a lot } & \text { watch-PER-P-SG-M] }
\end{array}
$$

S. $(3 ; 10.25): \quad$ 'I have watched a lot in Turkish.'

There are 18 correct examples in the corpus when S. uses perfective forms to describe a typical example in repeated situations. Example 15 illustrates one of them: 
(15)

$\begin{array}{lllllll}\text { S. }(3 ; 10.25): & \text { Поездy } & \text { куда } & \text { надо, } & \text { он } & \text { myda } & \text { nоедет. } \\ \text { S. }(3 ; 10.25): & \text { Pоеzdu } & \text { kuda } & \text { nado, } & \text { on } & \text { tuda } & \text { poedet. } \\ & \text { [train- } & \text { where } & \text { necessary } & \text { it-M-NOM } & \text { there } & \text { go-PER-FUT- } \\ & \text { DAT-SG } & & & & & \text { 3PRS-SG] }\end{array}$

S. (3;10.25): 'A train goes where it needs to go.'

The last meaning of a perfective form, that is describing possibilities in repeated situations, is found in the child's production nine times used correctly. Example 16 illustrates a typical use of the perfective aspect in this meaning:

$\begin{array}{lllllll}\text { S. }(3 ; 03.19): & \text { Она } & \text { выросла, } & \text { ее } & \text { махины } & \text { не } & \text { задавят. } \\ \text { S. }(3 ; 03.19): & \text { Ona } & \text { vyrosla, } & \text { eje } & \text { mašiny } & \text { ne } & \text { zadavjat. } \\ & \text { [she- } & \text { grow-PER- } & \text { she-ACC } & \text { car-NOM- } & \text { not } & \text { run over-PER- } \\ & \text { NOM } & \text { P-SG-F } & & \text { PL } & & \text { FUT-3PRS-PL] }\end{array}$

S. (3;03.19): 'She has grown up, cars will not run her over.'

Relying on the examples and data analysis presented above, we can conclude that $\mathrm{S}$. has acquired all meanings of the perfective aspect in Russian.

\subsection{Incorrect use of aspect in S.'s production}

The data analysis shows that there are only nine instances of incorrect use of aspectual forms out of total 1885 , which makes less than $1 \%$ of the aspectual forms produced by S. Five out of the nine errors in the use of RA occur due to the overuse of the aspectual form, as illustrated in Example 17, and four others happen in the formation of aspectual forms. Example 18 is illustrative.

$\begin{array}{lllll}\text { S. }(3 ; 07.21): & \text { В } & \text { ремонт } & \text { будем } & \text { ходить. } \\ \text { S. }(3 ; 07.21): & V & \text { remont } & \text { budem } & \text { hodit. } \\ & \text { [in } & \text { repair-ACC-SG } & \text { *will-FUT-1PRS-PL } & \text { go-IMPER-INF] }\end{array}$

S. (3;07.21): 'We will go to the repair shop.' 


\begin{tabular}{|c|c|c|c|c|c|c|}
\hline S. $(3 ; 04.20):$ & $\mathrm{OH}$ & $\operatorname{ma\kappa }$ & 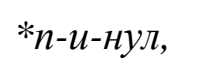 & $u$ & колобок & покатился. \\
\hline S. $(3 ; 04.20):$ & On & tak & $* p-i-n u l$ & $i$ & kolobok & pokatilsja. \\
\hline & [he-NOM & so & $\begin{array}{l}\text { kick-PER- } \\
\text { P-SG-M }\end{array}$ & and & kolobok-NOM & roll-PER-P-SG-M] \\
\hline
\end{tabular}

S. (3;04.20): ' 'He *kicked and kolobok rolled down.'

Though the instances of the incorrect aspect use are single cases and can be considered as very rare, it is relevant to say that all the instances of aspect overuse appear with motion verbs (see Example 17), which have been defined as exceptions to the core pattern of RA formation (see Table 1). This language behavior of S. is consistent with his monolingual counterparts, who are also known to make errors when they deal with exceptions to the main rule.

As for the errors due to the incorrect formation of aspectual forms, all of them are related to cases when aspect formation is marked either with sound alterations or omissions in the stem of the word. Thus, in Example 18, S. forms the perfective form by adding the suffix $н y-[-n u-]$ to the imperfective simplex пинать [pinat']-IMPER as *nинуть [pnut']-PER (kick); however, along with the suffix addition, the aspect formation in this case also requires the omission of the vowel $-u-[-i-]$ in the stem of the verb, which S. fails to omit. Such error patterns are also consistent with the findings of monolingual research as analogous errors are recorded in the production of monolingual Russian children (Ceytlin, 2000; Gvozdyev, 1961; Kiebzak-Mandera, 1997; 2000).

To sum up, relying on the data analysis related to the acquisition of RA by S. in the Turkish-dominant environment, the following conclusions can be drawn:

1. S. shows accurate use of RA as the use of more than $99 \%$ of aspectual forms found in the corpus are correct;

2. All meanings of RA appear in S.'s production;

3. The error patterns of few mistakes observed in S.'s data are consistent with monolingual research;

4. S.'s aspect acquisition in Russian has not revealed qualitatively different or incomplete pattern. 
Thus, our hypothesis that due to the reduced input and restricted use of Russian in the Turkish-dominant environment, the acquisition of RA by the bilingual participant will differ qualitatively from the monolingual pattern is not proven to be valid.

\section{Discussion}

This study examining the effect of the restricted input and use on the acquisition of RA by the Turkish-Russian bilingual child in the Turkish-dominant environment aims to investigate whether the bilingual Turkish-Russian participant can accurately use perfective and imperfective forms in their main meanings and whether his use of RA is marked with deviations from monolingual Russian data in terms of error rates and patterns. The results reveal that $\mathrm{S}$. has acquired RA in the Turkish-dominant environment in accordance with the monolingual Russian norms, and his use of RA is marked with no deviations from monolingual Russian data in terms of error rates and patterns. S. uses nearly all perfective and imperfective forms found in the corpus correctly. The perfective and imperfective forms are used in all their meanings. The patterns of very few errors (less than 1\%) found in S.'s production are consistent with the monolingual reports (Bar-Shalom, 2002; Ceytlin, 2000; Gagarina, 2000, 2007; Gvozdyev, 1961, 1981; Kiebzak-Mandera, 1997; 2000). Thus relying on the analysis of the verbal category of aspect, the present study supports the claim that despite the reduced input and use, the WL is acquired in the way similar to monolingual (Bonessen, 2006; Meisel, 2007; De Houwer, 1990), which may be considered as a piece of evidence in favour of the universal argument and supporting the idea that the reduced to a certain degree input is unlikely to cause qualitatively different and/or incomplete acquisition (Meisel, 2007).

The findings of this study challenge the results of the other studies investigating the acquisition of RA in different bilingual contexts (Gagarina et al., 2005; Ceytlin, 2009; Polinski, 2006; 2007) and arriving at the conclusion that the acquisition of RA by their bilingual participants differs from the monolingual norms both quantitatively and qualitatively. The difference between S.'s acquisition of RA and that of the bilinguals reported in the research on RA acquisition done so far (Ceytlin, 2009; Gagarina et al., 2005; Polinski, 2006; 2007) may be explained in relation to the issues that are discussed below.

First of all, the inconsistency in the acquisition of RA between S. and the other bilinguals may indirectly suggest the existence of a certain minimum threshold of the 
input within the critical period which is essential for monolingual-like acquisition. The question of how much minimum input in a language is required for a child to acquire this language has been raised by some scholars (Bonnesen, 2006; Montrul, 2008; Goldin-Meadow, 2006; Horowitz, 1987); however, though all of them refer to indirect evidence in favour of the threshold existence, none of them has been able to define the threshold quantitatively, mostly because the threshold cannot be considered as an absolute average quantity of the input since it is likely to depend on the constellation of different internal and external factors and would vary among individuals (Dopke, 1992). Based on this argument, our results allow us to speculate that in S.'s case, the quantity of the input is reduced but still it seems to reach and satisfy his threshold, which has allowed the child to acquire the category of RA in the monolingual-like manner. Such a look at the threshold in language acquisition as well as the difference in the acquisition of RA between $\mathrm{S}$. and the other bilingual participants indicate individual variations within the bilingual population and suggest the influence of extralinguistic factors on language acquisition.

Additionally, consistently with Laaha and Gillis (2007), it might be possible to attribute the accurate use of aspectual morphology of S. to the beneficial effect of two richly inflected languages in his repertoire, which has been suggested to enhance linguistic sensitivity to language acquisition.

Last but not least, as it has been highlighted by the anonymous reviewer, the participant of this study has acquired his Russian via communication with his mother, which is naturally marked with an intimate contact and long time spent together, all of which also contributes to his language acquisition.

To conclude, the study contributes to the discussion about the WL development in bilingual contexts and adds to the growing body of research looking at the development of a particular language in a variety of different contexts. The main limitation of this study concerns the issue of generalizability of the obtained results. Since the study is done relying on the data from the single bilingual child, all the findings, arguments and hypothesis require further validation. 
Abbreviation

$\begin{array}{ll}\text { ACC } & \text { Accusative } \\ \text { DAT } & \text { Dative } \\ \text { F } & \text { Feminine } \\ \text { FUT } & \text { Future } \\ \text { GEN } & \text { Genitive } \\ \text { IMP } & \text { Imperative } \\ \text { IMPER } & \text { Imperfective } \\ \text { INF } & \text { Infinitive } \\ \text { M } & \text { Masculine } \\ \text { NOM } & \text { Nominative } \\ \text { P } & \text { Past } \\ \text { PER } & \text { Perfective } \\ \text { PL } & \text { Plural } \\ \text { PR } & \text { Present } \\ \text { SG } & \text { Singular } \\ \text { 1PRS } & \text { 1st person } \\ \text { 2PRS } & \text { 2nd person } \\ \text { 3PRS } & \text { 3rd person }\end{array}$




\section{References}

Bar-Shalom, E. (2002). Tense and aspect in early child Russian. Language Acquisition $10,4,321-337$.

Bondarko, A. V. (1971). Vid i vremya russkogo glagola [Aspect and tense of the Russian verb]. Moskva: Prosveschenie.

Bonnesen, M. (2006). The status of the "weaker" language in unbalanced French/German bilingual language acquisition. Bilingualism: Language and Cognition 12(2), 177-192.

Brecht, R. (1984). The form and function of aspect in Russian. In M. Flier and R. Brecht (Eds.), Issues in Russian Morphosyntax (pp. 9-34). UCLA Slavic Studies 10, Columbus, Ohio.

Bybee, J. (1992). Tense, aspect, and mood. In W. Bright (Eds.), International Encyclopaedia of Linguistics, 4 (pp.144-145).

Cenoz, J. (2001). The effect of linguistic distance, L2 status, and age on crosslinguistic influence in third language acquisition. In J. Cenoz, B. Hufeisen and U. Jessner (Eds.), Cross-linguistic influence in third language acquisition: Psycholinguistic perspectives (pp. 8-20). Clevedon: Multilingual Matters.

Ceytlin, S. (2000). Jazyk i rebjenok: Lingvistika detskoi rechi [The language and the child: Linguistics of the child speech]. Gumanitarny izdatel'ski centr VLADOS.

Ceytlin, S. (2009). Grammaticheskie oshibki v osvojenii rebenkom Russkogo jazyka kak pervogo i kak vtorogo [Grammatical mistakes in the course of the acquisition of Russian as L1 and as L2]. Voprosy psycholingvistiki 9, 43-53.

Comrie, B. (1987). The World's Major Languages. London: Routledge.

De Houwer, A. (1990). Two at a time: an exploration of how children acquire two languages from birth. Cambridge: Cambridge University Press.

Dopke, S. (1992). One parent, one language: An interactional approach. Amsterdam, Philadelphia: John Benjamins Publishing Company.

Dopke, S. (2000a). The weaker language in simultaneous bilingualism: Why it is not like L2. Unpublished manuscript. Monash University.

Dopke, S. (2000b). Cross-linguistic structures in simultaneous bilingualism (Ed.). Amsterdam, Philadelphia: John Benjamins Publishing Company. 
Dornyei, Z. (2005). Psychology of the Language Learner: Individual Differences in Second Language Acquisition. London: Lawrence Erlbaum.

Erguvanli E. (1984). The function of word order in Turkish grammar. Berkeley: University of California Press.

Gagarina, N. (2000). The acquisition of aspectuality by Russian children: the early stages. ZAS Papers in Linguistics 15, 232-246.

Gagarina, N. (2007). Stanovlenie funkcional'no-semanticheskogo polja aspektual'nosti $v$ detskoi rechi [Formation of the functional-semantic field in the child speech] In S. Ceytlin (Ed.), Semanticheskie kategorii v detskoj rechi [Semantic categories in the child speech] (pp.18-40). St. Petersburg: Nestor-Historia.

Gagarina, N., Armon-Lotem, S., \& Gupol, O. (2005). A story of errors: Inflections in the Russian verbal system of Russian-Hebrew sequential bilinguals and Russian monolinguals. $10^{\text {th }}$ Congress of the International Association for the Study of Child Language Conference. Berlin.

Göksel, A., \& Kerslake, C. (2005). [Third reprint 2010]. Turkish, a comprehensive grammar. London, UK: Routledge.

Goldin-Meadow, S. (2006). How children learn language: A focus on resilience. In McCartney, K. And Phillips, D. (Eds.) Blackwell handbook of early childhood development (pp. 252-274). Blackwell Publishing.

Gvozdyev, A. (1961). Voprosy izuchenija detskoy rechi. [Child speech studies.]. Moscow: Rossijskaja Akademija Nauk.

Gvozdyev, A. (1981). Ot pervyh slov do pervogo klassa. Dnevnik nauchnyh nabludeniy [From the first words to the first grade. The diary of scientific observations]. Saratov: Saratovsky universitet.

Hoffmann, (1991). Introduction to bilingualism. New-York: Longman Group.

Horowitz, F. D. (1987). Exploring developmental theories: toward a structural/behavioral model of development. Lawrence Erlbaum Associates Inc.

Hulk, A., \& Mueller, N. (2000). Bilingual first language acquisition at the interface between syntax and pragmatics. Bilingualism: Language and Cognition, 3(3), 227-244.

Kamynina, A. (1999). Sovremennyi Russkij jazyk. Morfologija. [Modern Russian language. Morphology]. Moscow: Moskovskij Universitet. 
Kartsevskii, S. (1927). Système du verbe russe. Essai de linguistique synchronique. Prague.

Kiebzak-Mandera, D. (1997). The use of aspectual forms by a two-year-old Russian child. Psychology of Language and Communication 1 (1), 83-97.

Kiebzak-Mandera, D. (2000) Formation of the verb system in Russian children. Psychology of Language and Communication 4 (1), 27-46.

Kornfilt, J. (1997). Turkish. London, UK/New York, NY: Routledge

.Laaha, S., \& Gillis, S. (2007). Typological perspectives on the acquisition of noun and verb morphology. Antwerp papers in linguistics 112.

La Morgia, F. (2011). Bilingual First Language Acquisition: The Nature of the Weak Language and the Role of the Input. Unpublished PhD Thesis, Dublin City University.

Maslov, U. (1984). Ocherki po aspektologii [Essays on the aspectology]. Leningrad: Leningrad University Press.

Meisel, J. (2007). The weaker language in early child bilingualism: Acquiring a first language as a second language? Applied Psycholinguistics 28, 495-514.

Montrul, S. (2004). The acquisition of Spanish. Morphosyntactic development in monolingual and bilingual L1 acquisition and in Adult L2 acquisition. [Series on language acquisition and language disorders]. Amsterdam: John Benjamins Publishing Company.

Montrul, S. (2008). Incomplete acquisition in bilingualism: re-examining the age factor. Amsterdam, Philadelphia: John Benjamins Publishing Company.

Mueller, N. (1998). Transfer in bilingual first language acquisition. Bilingualism: Language and Cognition 1 (3), 151-171.

Nicoladis, E., \& Paradis, J. (2012). Acquiring regular and irregular past tense morphemes in English and French: Evidence from bilingual children. Language Learning 62:1, pp. 170-197.

Odlin, T. (1989). Language transfer. Cambridge, UK: Cambridge University Press.

Paradis, J., \& Genesee, F. (1996). Syntactic acquisition in bilingual children: Autonomous or interdependent? Studies in Second Language Acquisition 18, $1-25$.

Polinski, M. (2006). Incomplete acquisition: American Russian. Journal of Slavic Linguistics 14(2), 191-262. 
Polinski, M. (2007). Acquisition of Russian: Uninterrupted and incomplete scenarios. The Slavic and East European Language Research Center. Retrieved from http://seelrc.org/glossos/.

Pupynin, U. (1996). Usvoeniye sistemy Russkih glagolnyh form (ranniye etapy) [Acquisition of the system of the Russian verbal forms (early stages)]. Voprosy jazykoznanija 3, 102 -117.

Schlyter, S. (1993). The weaker language in bilingual Swedish-French children. In K. Hyltenstam and A. Viberg (Eds.), Progression and regression in language: Sociocultural, neuropsychological and linguistic perspectives (pp. 289-308). Cambridge: Cambridge University Press.

Schlyter, S., \& Hakansson, G. (1994). Word order in Swedish as the first language, second language and weaker language in bilinguals. Scandinavian Working Papers on Bilingualism 9, 49-66.

Stoll, S. E. (2001). The Acquisition of Russian Aspect. An unpublished dissertation. University of California, Berkeley.

Timberlake, A. (1993). Russian. In B. Comrie and G. G. Corbett (Eds.), The Slavonic languages (pp. 827 -887). London: Routledge.

Timberlake, A. (2004). A Reference Grammar of Russian. Cambridge: Cambridge University Press.

Vinnitskaya, I., \& Wexler, K. (2001). The role of pragmatics in the development of Russian aspect. First Language 21, 143-186.

Yip, V., \& Matthew, S. (2007). The bilingual child. Early development and language contact. Cambridge: Cambridge University Press. 